\title{
並列梯形ラーメンの二,三の性状並びに影響線について*
}

$$
\text { 正員星治雄** }
$$

\section{ON SOME CHARACTERS AND INFLUENCE LINES \\ OF PARALLEL TRAPEZOIDAL RIGID FRAMES}

By Haruo Hoshi, C.E. Member

Synopsis: When parallel trapezoidal rigid frames are connected with cross beams, each main beam takes its share of deformation and stress mutually, by the distributing action of cross beams, as in ladder girders. The rate of the distributing action depends on $i$ ) inclination of frame legs, ii)ratio of flexural rigidity of main beam to that of cross beam, iii) ratio of the distances between the main beams and the cross beams and iv) other factors, etc. Taking the above facts into consideration, some properties of these structures and the method of drawing the influerce lines are discussed and a numerical example is presented.

要 旨 並列梯形ラーメンを横析で連結した場合，梯子桁の場合と同じように，横妳による荷重の配 分作用注って, 各主枌は相互に変形ならびマ応力を分担する。その状況はラーメンの脚の角度, 主桁 と横析との曲げ剛性比，主桁間隔と横桁間隔との比，その他によつて異なつてくる。そのよろな見地に 颃いて，並列梯形ラーメンの若干の性状を検討し，かつ影響線の作成について述へ，計算例を添えたも ので岗る。

\section{1. 緒論}

立体ラーメンの解法については，従来多くの研究が発表せられている。これを実際に適用する際には，その釣 合条件式の立て方，並びそ釗合条件式による 連立方程式の解法手段などが緊要な問題となつてくる。従つて，実 際の構造物さ解くには，以上に対する十分なる考慮が必要である。な招また，移動荷重を取りあつかう場合は， 固定荷重のみを取り扱う場合とは異なつた考慮が必要で, 連立方程式の係数行列の逆行列を求めるのが最も好都 合であると思われる。

しかし，いずれにしても，構造物の複難さの程度を増せば，それにつれて労力は急激に大きくなる。それで不 静定次数がある程度内ならぼ，精密計算式を実用的に適用，実施することができるが，不静定度が余り高けれ ば，略算法が考虑されねばならない。一方これとは別と，不静定次数の高いるのが，簡単な構造よりも，はたし て実用的に高度の価值括よび効果を有するかどうかる検討さるべき問題である。要はとの構造に対する定性的性 質を十分に見究めて，合目的であつて，乙かも有利な形状，寸法並びと構法を知る必要がある。

そこで相当利用度の高いと考えられる並列梯形ラーメン（梯形ラーメンを並列して，横析で璉結して，立体ラ ーメンとしたもの）について若干の考察を試みた。

主桁の仮想断面としては，ねじり剛性の大きいるのを採用した。その理由は，横枌の曲げ剛性並びマねじり剛 性は主桁の荷重配分に大きい影響を招よぼさないが，主桁のねじり剛性は相当大きい影響を有するからである。

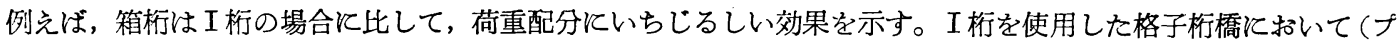
レート・ガーダー並列の単純析橋として設計されたものに括いてさえ), 実験の結果, 相当量の荷重配分を示して いるのは，床版との共同作用によるのであつて，格子の骨組のみでは荷重配分の割合は小である。本文としては 床版との共同作用を考皇ないで，骨組だけを独立させて考虑するのであるから，主林としては特にねじり剛性の 大きいものを想定した。

\section{2. 解 法 概 要}

並列梯形ラーメンの解法は変形法により, その釣合条件式を 誘導するのに次のようにした"

任意の位置にある立体ラーメンの 1 部材について，まず図一 1 のように直交座標軸をとり, それに対する関係式を求め, 次 に任意の直交座標軸への変換を行い, 座標軸に対して任意の位

* 土木学会, 昭和 31 年度年次大会に招いて一部発表

**徳島大学教授, 工学部土木工学教室

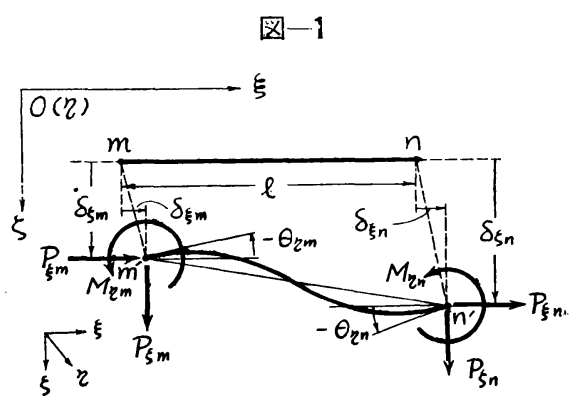


㯰にある部材に対する一般式を提示した。その際, 取り扱う力, モーメント, 変形, 変位などをあらわす各べクト ル量の符号は，すべて座標軸の方向に準抛するすのとする。

図一1 について，任意の 1 部材 $m n$ の $\xi \zeta$ 面内での変形（空間に猢る実変形の $\boldsymbol{\xi} \zeta$ 面への投影）を考兄る。 さて点 $m$ に力 $P_{\zeta m}$ 执よびモーメント $M_{\eta m}$ が作用して, 部材 $m n$ が図のように変形拉よび変位を受けた場合, その曲げ変形は

$$
-B_{\eta} \frac{d^{2} \zeta}{d \xi^{2}}=-M_{\eta m}-P_{\zeta m} \cdot \xi
$$

となる。これを 1 度および 2 度積分して, 点 $m, n$ と搢ける境界条件

$$
\begin{aligned}
& \text { ( })_{\xi=0}=\delta_{\zeta m} \quad\left(\frac{d \zeta}{d \xi}\right)_{\xi=0}=-\theta_{\eta m}
\end{aligned}
$$

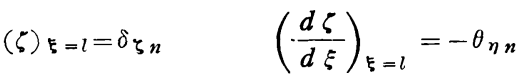

を入れると，次の関係式を得る。

$$
\begin{aligned}
P_{\zeta m} & =\frac{12 B_{\eta}}{l^{3}}\left(\delta_{\zeta m}-\delta_{\zeta n}\right)-\frac{6 B_{\eta}}{l^{2}}\left(\theta_{\eta_{m}}+\theta_{\eta n}\right) \\
M_{\eta m} & =-\frac{6 B_{\eta}}{l^{2}}\left(\delta_{\zeta m}-\delta_{\zeta n}\right)+\frac{2 B_{\eta}}{l}\left(2 \theta_{\eta_{m}}+\theta_{\eta n}\right)
\end{aligned}
$$

$\xi \eta$ 面に対しても全く同じょうな関係式が得られる。

いま $\xi \zeta$ 面に括いて, 図一1 のように変形, 変位をろけた状態で部材の両端を拘束した場合, 点 $m$ の拘束に作 用する力拉よびモーメントをそれぞれ $\mathfrak{S}_{\zeta m}, \mathfrak{M}_{\eta m}$ と置くと

$$
\begin{aligned}
& \mathfrak{P}_{\zeta_{m}}=-\frac{12 B_{\eta}}{l^{3}}\left(\delta_{\zeta_{m}}-\delta_{\zeta n}\right)+\frac{6 B_{\eta}}{l^{2}}\left(\theta_{\eta m}+\theta_{\eta_{n}}\right) \\
& \mathfrak{M}_{\eta m}=\frac{6 B_{\eta}}{l^{2}}\left(\delta_{\zeta_{m}}-\delta_{\zeta_{n}}\right)-\frac{2 B_{\eta}}{l}\left(2 \theta_{\eta m}+\theta_{\eta n}\right)
\end{aligned}
$$

同じようにして $\xi \eta$ 面に対しては

$$
\begin{aligned}
& \mathfrak{P}_{\eta m}=-\frac{12 B_{\zeta}}{l^{3}}\left(\delta_{\eta m}-\delta_{\eta n}\right)+\frac{6 B_{\zeta}}{l^{2}}\left(\theta_{\zeta m}+\theta \ddot{\zeta}_{n}\right) \\
& \mathfrak{M}_{\zeta m}=\frac{6 B_{\zeta}}{l^{2}}\left(\delta_{\eta_{m}}-\delta_{\eta n}\right)-\frac{2 B_{\zeta}}{l}\left(2 \theta_{\zeta m}+\theta_{\zeta n}\right)
\end{aligned}
$$

次に軸方向力およびねじりに対しては

となる。上式中

$$
\begin{aligned}
& \mathfrak{P}_{\xi m}=-\frac{E F}{l}\left(\delta_{\xi_{m}}-\delta_{\xi n}\right) \\
& \mathfrak{M}_{\xi m}=-\frac{C}{l}\left(\theta_{\xi_{m}}-\theta_{\xi}\right)
\end{aligned}
$$

\section{$B_{\eta}: \xi \zeta$ 面内にある部材のその面に関する曲げ剛性 \\ $B_{\zeta}: \xi \eta$ 面内にある部材のその面に関する曲げ剛性 \\ $C:$ 部材のねじり剛性}

i'次飞 $\xi, \eta, \zeta$ 軸に対し, 方向余弦がそれぞれ $\alpha_{1}, \beta_{1}, \gamma_{1} ; \alpha_{2}, \beta_{2}, \gamma_{2} ; \alpha_{3}, \beta_{3}, \gamma_{3}$ であるような新しい直交座標軸 $x$, $\boldsymbol{y}, \boldsymbol{z}$ 飞座標変換を行う。すると $\mathfrak{P}, \mathfrak{M}, \delta, \theta$ などの諸量の新旧座標軸に関する関係式は次のようになる。

$$
\begin{aligned}
& \mathfrak{M}_{x}=\alpha_{1} \mathfrak{M}_{\xi}+\beta_{1} \mathfrak{M}_{\eta}+r_{1} \mathfrak{M}_{\zeta} \\
& \mathfrak{M}_{y}=\alpha_{2} \mathfrak{M}_{\xi}+\beta_{2} \mathfrak{M}_{\eta}+r_{2} \mathfrak{M}_{\zeta} \\
& \mathfrak{M}_{z}=\alpha_{3} \mathfrak{M}_{\xi}+\beta_{3} \mathfrak{M}_{\eta}+\gamma_{3} \mathfrak{M}_{\zeta} \\
& \mathfrak{P}_{x}=\alpha_{1} \mathfrak{P}_{\xi}+\beta_{1} \mathfrak{P}_{\eta}+r_{1} \mathfrak{B}_{\zeta} \\
& \mathfrak{P}_{y}=\alpha_{2} \mathfrak{P}_{\xi}+\beta_{2} \mathfrak{P}_{\eta}+r_{2} \mathfrak{P}_{\zeta} \\
& \mathfrak{P}_{z}=\alpha_{3} \mathfrak{P}_{\xi}+\beta_{3} \mathfrak{P}_{\eta}+r_{3} \mathfrak{B}_{\zeta}
\end{aligned}
$$

拈よび

$$
\begin{aligned}
& \delta_{\xi}=\alpha_{1} \delta_{x}+\alpha_{2} \delta_{y}+\alpha_{3} \delta_{z} \\
& \delta_{\eta}=\beta_{1} \delta_{x}+\beta_{2} \delta_{y}+\beta_{3} \delta_{z} \\
& \delta_{\zeta}=r_{1} \delta_{x}+\gamma_{2} \delta_{y}+\gamma_{3} \delta_{z} \\
& \theta_{\xi}=\alpha_{1} \theta_{x}+\alpha_{2} \theta_{y}+\alpha_{3} \theta_{z} \\
& \theta_{\eta}=\beta_{1} \theta_{x}+\beta_{2} \theta_{y}+\beta_{3} \theta_{z} \\
& \theta_{\zeta}=r_{1} \theta_{x}+r_{2} \theta_{y}+r_{3} \theta_{z} .
\end{aligned}
$$


以上に括いて，式 (5)，(6) 飞(2)，(3)，(4) の関係を入れ, 式中の変形量には式 (7)，(8) に示される関係 式を入れる。そしてその結果を整理すると次のようになる。

$$
\begin{aligned}
& \mathfrak{P}_{x m}=-\frac{12}{l^{3}}\left[\left(\beta_{1}^{2} B_{\zeta}+r_{1}^{2} B_{\eta}\right)\left(\delta_{x m}-\delta_{x n}\right)+\left(\beta_{1} \beta_{2} B_{\zeta}+r_{1} r_{2} B_{\eta}\right)\left(\delta_{y m}-\delta_{y n}\right)+\left(\beta_{1} \beta_{3} B_{\zeta}+\gamma_{1} \gamma_{3} B_{\eta}\right)\left(\delta_{z m}-\delta_{z n}\right)\right] \\
& +\frac{6}{l^{2}}\left[\beta_{1} \gamma_{1}\left(B_{\zeta}+B_{\eta}\right)\left(\theta_{x m}+\theta_{x n}\right)+\left(\beta_{1} \gamma_{2} B_{\zeta}+\beta_{2} \gamma_{1} B_{\eta}\right)\left(\theta_{y m}+\theta_{y n}\right)+\left(\beta_{1} \gamma_{3} B_{\zeta}+\beta_{3} \gamma_{1} B_{\eta}\right)\left(\theta_{z m}+\theta_{z n}\right)\right] \\
& \mathfrak{\beta}_{y m}=-\frac{12}{l^{3}}\left[\left(\beta_{1} \beta_{2} B_{\zeta}+\gamma_{1} \gamma_{2} B_{\eta}\right)\left(\delta_{x m}-\delta_{x n}\right)+\left({\beta_{2}}^{2} B_{\zeta}+{\gamma_{2}}^{2} B_{\eta}\right)\left(\delta_{y m}-\delta_{y n}\right)+\left(\beta_{2} \beta_{3} B_{\zeta}+\gamma_{2} \gamma_{3} B_{\eta}\right)\left(\delta_{z m}-\delta_{z n}\right)\right] \\
& +\frac{6}{l^{2}}\left[\left(\beta_{2} r_{1} B_{\zeta}+\beta_{1} r_{2} B_{\eta}\right)\left(\theta_{x m}+\theta_{x n}\right)+\beta_{2} r_{2}\left(B_{\zeta}+B_{\eta}\right)\left(\theta_{y m}+\theta_{y n}\right)+\left(\beta_{2} r_{3} B_{\zeta}+\beta_{3} r_{2} B_{\eta}\right)\left(\theta_{z m}+\theta_{z n}\right)\right] \\
& \mathfrak{P}_{z m}=-\frac{12}{l^{3}}\left[\left(\beta_{1} \beta_{3} B_{\zeta}+\gamma_{1} \gamma_{3} B_{\eta}\right)\left(\delta_{x m}-\delta_{x n}\right)+\left(\beta_{2} \beta_{3} B_{\zeta}+\gamma_{2} \gamma_{3} B_{\eta}\right)\left(\delta_{y m}-\delta_{y n}\right)+\left(\beta_{3}{ }^{2} B_{\zeta}+\gamma_{3}{ }^{2} B_{\eta}\right)\left(\delta_{z m}-\hat{\delta}_{z n}\right)\right] \\
& +\frac{6}{l^{2}}\left[\left(\beta_{3} \gamma_{1} B_{\zeta}+\beta_{1} \gamma_{3} B_{\eta}\right)\left(\theta_{x m}+\theta_{x n}\right)+\left(\beta_{3} \gamma_{2} B_{\zeta}+\beta_{2} r_{3} B_{\eta}\right)\left(\theta_{y m}+\theta_{y n}\right)+\beta_{3} r_{3}\left(B_{\zeta}+B_{\eta}\right)\left(\theta_{z m}+\theta_{z n}\right)\right] \\
& \mathbb{M}_{x m}=-\frac{C}{l}\left[\alpha_{1}{ }^{2}\left(\theta_{x m}-\theta_{x n}\right)+\alpha_{1} \alpha_{2}\left(\theta_{y m}-\theta_{y n}\right)+\alpha_{1} \alpha_{3}\left(\theta_{z m}-\theta_{z n}\right)\right] \\
& +\frac{6}{l^{2}}\left[\beta_{1} \gamma_{1}\left(B_{\eta}+B_{\zeta}\right)\left(\delta_{x m}-\delta_{x n}\right)+\left(\beta_{1} \gamma_{2} B_{\eta}+\beta_{2} r_{1} B_{\zeta}\right)\left(\delta_{y m}-\delta_{y n}\right)+\left(\beta_{1} \gamma_{3} B_{\eta}+\beta_{3} \gamma_{1} B_{\zeta}\right)\left(\delta_{z m}-\delta_{z n}\right)\right] \\
& -\frac{2}{l}\left[\left(\beta_{1}^{2} B_{\eta}+{\gamma_{1}}^{2} B_{\zeta}\right)\left(2 \theta_{x m}+\theta_{x n}\right)+\left(\beta_{1} \beta_{2} B_{\eta}+r_{1} r_{2} B_{\zeta}\right)\left(2 \theta_{y m}+\theta_{y n}\right)\right. \\
& \left.+\left(\beta_{1} \beta_{3} B_{\eta}+\gamma_{1} \gamma_{3} B_{\zeta}\right)\left(2 \theta_{z m}+\theta_{z n}\right)\right] \\
& \mathfrak{M}_{y m}=-\frac{\boldsymbol{C}}{l}\left[\alpha_{1} \alpha_{2}\left(\theta_{x m}-\theta_{x n}\right)+\alpha_{2}^{2}\left(\theta_{y m}-\theta_{y n}\right)+\alpha_{2} \alpha_{3}\left(\theta_{z m}-\theta_{z n}\right)\right] \\
& +\frac{6}{l^{2}}\left[\left(\beta_{2} \gamma_{1} B_{\eta}+\beta_{1} \gamma_{2} B_{\zeta}\right)\left(\delta_{x m}-\delta_{x n}\right)+\beta_{2} \gamma_{2}\left(B_{\eta}+B_{\zeta}\right)\left(\delta_{y m}-\delta_{y n}\right)+\left(\beta_{2} \gamma_{3} B_{\eta}+\beta_{3} \gamma_{2} B_{\zeta}\right)\left(\delta_{z m}-\delta_{z n}\right)\right] \\
& -\frac{2}{l}\left[\left(\beta_{1} \beta_{2} B_{\eta}+\gamma_{1} \gamma_{2} B_{\zeta}\right)\left(2 \theta_{x m}+\theta_{x n}\right)+\left(\beta_{2}^{2} B_{\eta}+\gamma_{2}^{2} B_{\zeta}\right)\left(2 \theta_{y m}+\theta_{y n}\right)\right. \\
& \left.+\left(\beta_{2} \beta_{3} B_{\eta}+\gamma_{2} \gamma_{3} B_{\zeta}\right)\left(2 \theta_{z m}+\theta_{z n}\right)\right] \\
& \mathfrak{M}_{z m}=-\frac{C}{l}\left[\alpha_{1} \alpha_{3}\left(\theta_{x m}-\theta_{x n}\right)+\alpha_{2} \alpha_{3}\left(\theta_{y m}-\theta_{y n}\right)+\alpha_{3}{ }^{2}\left(\theta_{z m}-\theta_{z n}\right)\right] \\
& +\frac{6}{l^{2}}\left[\left(\beta_{3} \gamma_{1} B_{\eta}+\beta_{1} \gamma_{3} B_{\zeta}\right)\left(\delta_{x m}-\delta_{x n}\right)+\left(\beta_{3} \gamma_{2} B_{\eta}+\beta_{2} \gamma_{3} B_{\zeta}\right)\left(\delta_{y m}-\delta_{y n}\right)+\beta_{3} \gamma_{3}\left(B_{\eta}+B_{\zeta}\right)\left(\delta_{z m}-\delta_{z n}\right)\right] \\
& -\frac{2}{l}\left[\left(\beta_{1} \beta_{3} B_{\eta}+\gamma_{1} \gamma_{3} B_{\zeta}\right)\left(2 \theta_{x m}+\theta_{x n}\right)+\left(\beta_{2} \beta_{3} B_{\eta}+r_{2} r_{3} B_{\zeta}\right)\left(2 \theta_{y m}+\theta_{y n}\right)\right. \\
& \left.+\left(\beta_{3}{ }^{2} B_{\eta}+\gamma_{3}{ }^{2} B_{\zeta}\right)\left(2 \theta_{z m}+\theta_{z n}\right)\right]
\end{aligned}
$$

式 (9), (10) は部材端 $m, n$ 飞招いて, 点 $m$ 飞変位 $\delta_{x m}, \delta_{y m}, \delta_{z m}$, 回転 $\theta_{x m}, \theta_{y m}, \theta_{z m} ;$ 点 $n$ 飞変位 $\delta_{x n}, \delta_{y n}$, $\delta_{z n}$, 回転 $\theta_{x n}, \theta_{y n}, \theta_{z n}$ を与えた状態で拘束したとき, 部材の変形のために点 $m$ と辌いて, 拘束に作用する力及 びモーメントである。

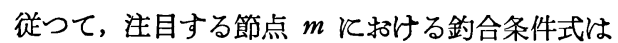

$$
\begin{aligned}
& \Sigma \mathfrak{B}_{x m}+P_{x m}=0 \\
& \Sigma \mathfrak{B}_{y m}+P_{y m}=0 \\
& \Sigma \mathfrak{P}_{z m}+P_{z m}=0 \\
& \Sigma \mathfrak{M}_{x m}+M_{x m}=0 \\
& \Sigma \mathfrak{M}_{y m}+M_{y m}=0 \\
& \Sigma \mathfrak{M}_{z m}+M_{z m}=0
\end{aligned}
$$

となる2)。ただし $P_{x m}, P_{y m}, P_{z m}$ および $M_{x m}, M_{y m}, M_{z m}$ は点 $m$ と作用する外力およびモーメントのそれぞれ の方向に関する成分である。

\section{3. 演算に対する仮定並びに考虑}

計算例並びそ性状検討のための計算は次のような仮定並びそ考虑の下に行つた。

（1）主枌の曲げ剛性 $B_{1}$ とねじり剛性 $C_{1}$ との比は一定であるとした。それは箱枌として有利と考兄られ

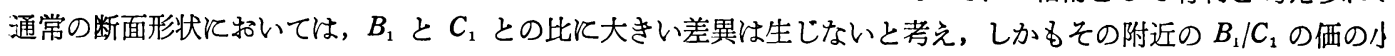




$$
E F_{1}=2.2 \times 10^{\circ} \mathrm{kg} \quad E F_{2}=0
$$

上式中, 添字 1 は主析に関する諸量, 添字 2 は横析に関する諸量を示 し， $B_{1}{ }^{\prime}, B_{2}{ }^{\prime}$ はそれぞれの横曲げ剛性である。な特 $B_{2}{ }^{\prime}, C_{2}$ および横桁 の軸方向力はこれらを無視した。以上の数值を使用して表一1の連立方 程式を解き, 図示の荷重に対する両主析の曲げモーメント図を描くと図 -2(b)のよろとなる。

\section{5. 若干の性状並びに考察}

図一2 のような並列梯形ラーメンに括いて，(a) 角 $\phi$ を変化した場 合，（b） $l_{2} / l_{1}$ を変化した場合，(c) $B_{2} / B_{1}$ を変化した場合，なぞについ て各変形量の有样を考察した。その大要は次のと招りである。

(a) 脚の傾斜角 $\phi$ の変化飞よる各変形量の状況

単一鉛直格点荷重が作用する場合, $\phi=90^{\circ} \rightarrow 0^{\circ}$ のものとついて各節点 の変位 $\delta$ 抢よび回転角 $\theta$ の変化の状況は図一 $3,4,5$ のよろである。以上 より注目すべき点は

1. $\delta_{x}$ とついては変形量の配分効果は $\phi$ の減少とともに増大する。

2. 並列梯形ラーメンの各相当格点の主析方向水平変位量の和, 例兄 ば $\delta_{x_{1}}+\delta_{x_{1}}$ は単一梯形ラーメンに招ける, この格点の水平変位量に等 しい。

3. $\delta_{x_{1}}$ と $\delta_{x_{2}}$ との間の縦距の差は部材 12 そ淤ける軸方向力飞比例するが，これる角 $\phi^{\prime}$ の減少と共に增大す る。

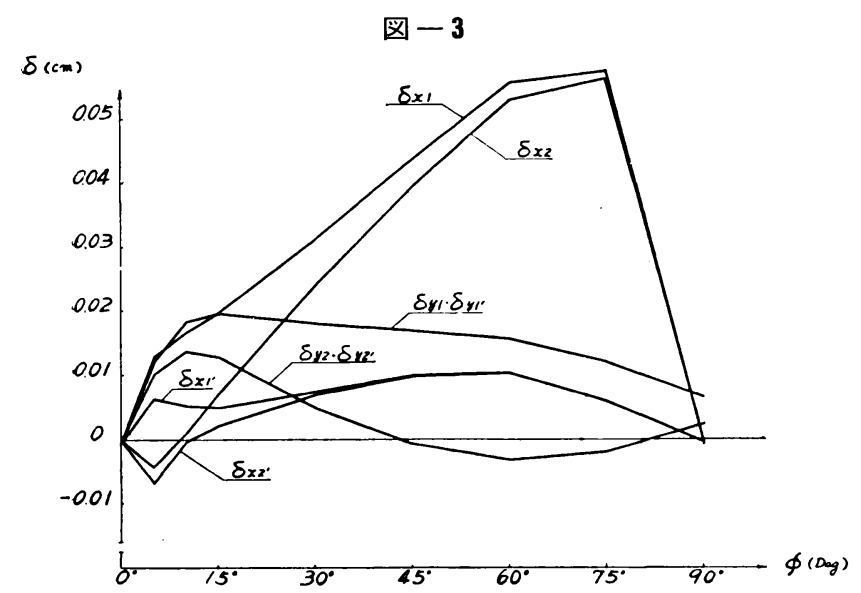

$\delta x(\mathrm{~cm})$

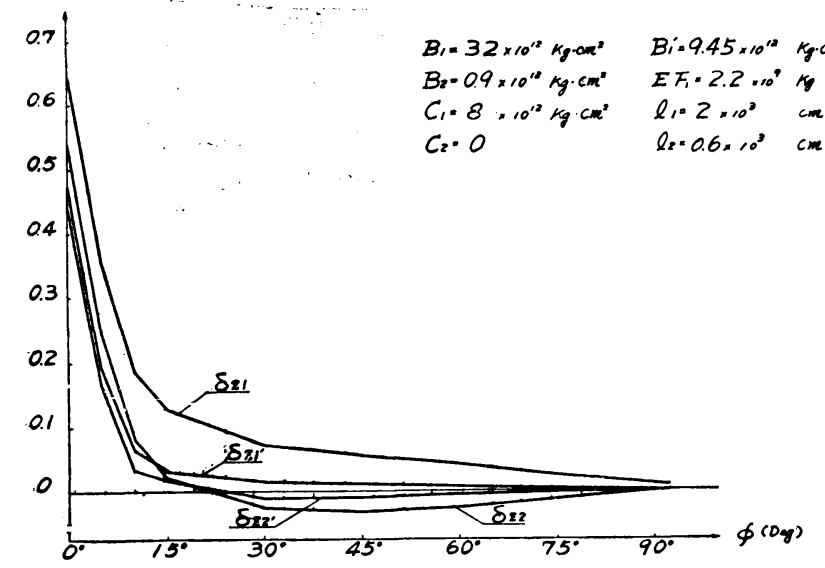

(a)

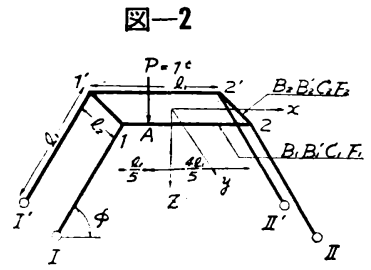

(b)
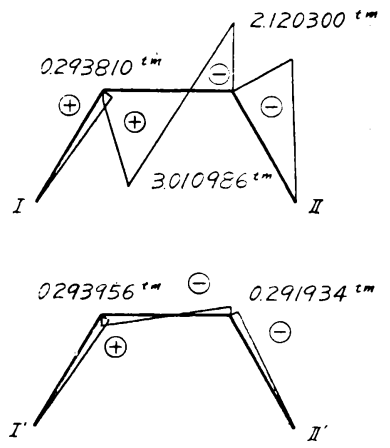

4. oy とついては $\phi$ が招招よそ $45^{\circ} \sim 80^{\circ}$ 間では $\delta_{y_{1}}$ と $\delta_{y_{2}}$ とは変 位方向が相反する。これは $\theta_{x}$ の図 表と相関している。

5. $\grave{z}_{z}$ そついては, 荷重の作用し ない方の相当格点 2 おょび 2 の夕 ワミはラーメンが相当に拥平になる までは負であり，荷重作用点とつい ては $\phi$ が大きいと荷重配分が悪い

6. $\phi=90^{\circ}$ のときの $\delta_{z}$ は部材め 軸方向力による部材変形を示し, $\phi=0^{\circ}$ のときのタワミは梯子桁の華 れである。

(b) $l_{2} / l_{1}$ の変化による各変形量 の状況

$\phi=60^{\circ}$ の場合, $l_{2} / l_{1}=0.1 \sim 1.0 \Phi$ 間について，それに応じる各変位招 よび回転角の変化を見れば，その状 況は図一6,7 の通りで, 注目すべき 点としては,

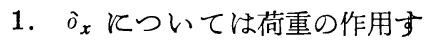
る方の主桁と作用しない方の主桁と の水平変位の配分の有様は梯子枌に 招けるタワミ $\delta$ の変化の状況と似て いて, $\hat{o}_{x_{1}}$ と $\delta_{x_{2}}$ との差, すなわち 軸方向力の影響は注とんで一定であ る。

2. $\delta_{z}$ そついては, $\delta_{z 1}$ と $\delta_{z 1}$, 
図 -5

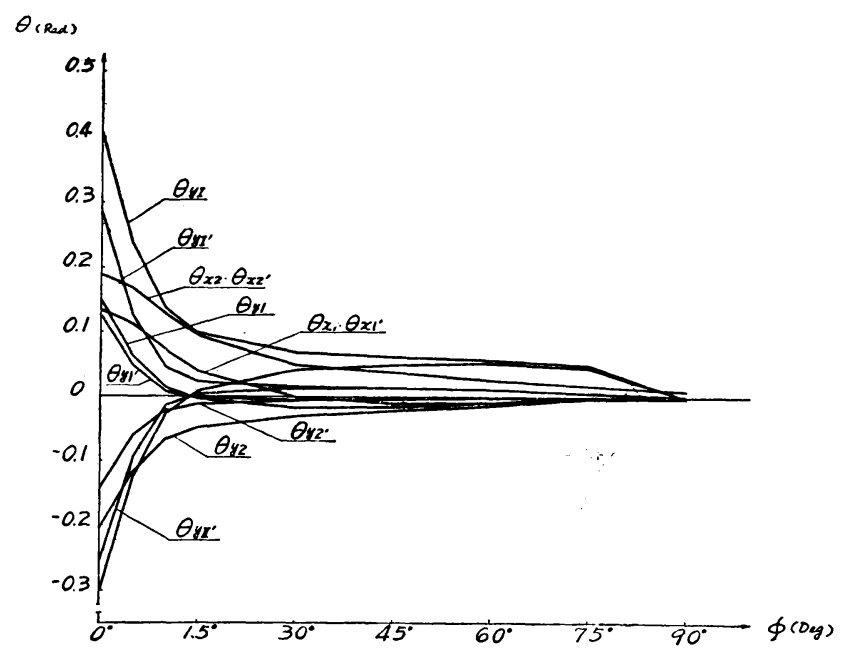

$\theta(\operatorname{Rac})$

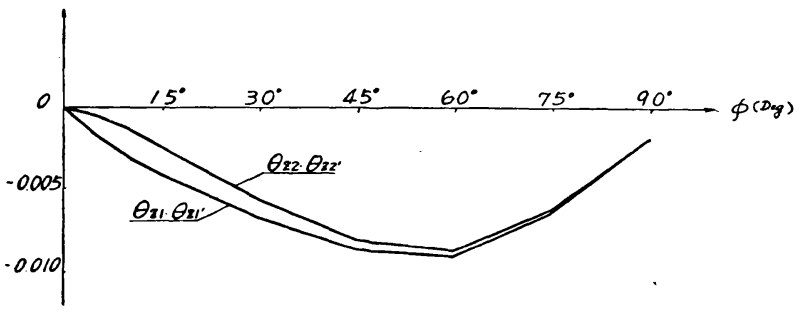

図-6

$\$ .60^{\circ} \quad B_{1} \cdot 32 \times 10^{18} \mathrm{~kg} \cdot \mathrm{cm}^{2}$ $B_{2}=0.9 \times 10^{12} \mathrm{~kg} \cdot \mathrm{cm}^{2}$ $C_{1} \cdot 8 \times 10^{12} \mathrm{~kg} \cdot \mathrm{cm}^{2}$

$B_{i}=9.45 \times 10^{\circ 2} \mathrm{~kg}^{2 \mathrm{~cm}^{2}}$ $E F_{1}=2.2 \times 10^{\circ} \mathrm{kg}$ $Q_{1}=2 \times 10^{\circ} \mathrm{cm}$

$\delta(c m)$

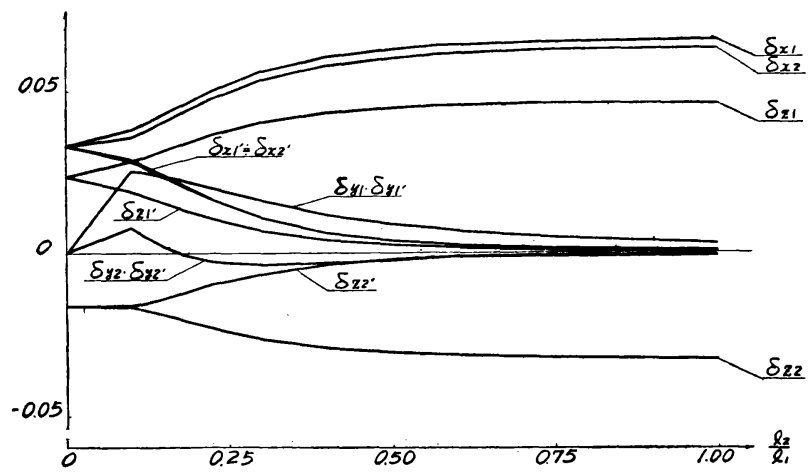

との関係怙よび $\delta_{z 1}$ の変化の状況 は，梯子枌に招ける $\delta_{1}$ と $\delta_{1^{\prime}}$ との 関係招よび $\delta_{1}$ の変化の状況と同じ ようである。

3. $\delta_{z 2}$ と $\delta_{z z^{\prime}}$ との関係も上述 と同じようであるが，この価は負で ある。

(c) $B_{2} / B_{1}$ の変化に上る各変形 量の状況

$\phi=60^{\circ}$ の場合について， $B_{2} / B_{1}$ を 変化させて，それ応じる各変位招 よで回転角の変化の状況は大体次の と招りである(図一8,9)。

1. $\delta_{z}$ については梯子析の場合 と同じようであるが， $\delta_{z 2}$ は負であ る。ある程度以上 $B_{2}$ が大きくなれ ば荷重配分に扣よぼす影響は小とな り，梯子桁と同し傾向である。

2. $\delta_{x}$ についてもほぼ同様であ つて，ある程度以上の $B_{2}$ の増大は 荷重配分に括よぼす効果が僅少にな る。

\section{6. 置換荷重およひ影䉜線}

先に梯子析について，計算を簡易 化するために，その基本的単純バリ 飞対する置換荷重 ${ }^{2}$ を求めたのと同 じうと，並列梯形ラーメンの基本 的梯形ラーメンに対する置換荷重を 求めることができる。置換荷重は実 際荷重に格点の拘束力を重㸚合わし たもので，図一10 は格点 1 亿括け る拘束力の影響線"である。従つて これを利用して, 置換荷重を求める ことができる。例党ば，格点 1 亿 $P=1$ が作用するときの 置換荷重の 絶対值はそれぞれ $1,1^{\prime}, 2,2^{\prime}$ と打け る影響線の縦距から直ちに求められ る。ただしこの場合, 基本形が梯形 ラーメンであるから, 水平拘束力の 影響が加味されるべきであるが，横

枍の横曲げ剛性 $B_{2}{ }^{\prime}$ を無視しているので，これは省略されている***。

次に断面力の影響線は梯子枌に対して発表したところ と) と同じょうに，格点の拘束力の影響線を利用して，こ れを求めることができる。すなわち格点に括ける拘束力を外力と考えた基本的梯形ラーメンとして，その影響線

*** 横行の横曲げ剛性の影響——

上述の計算例の場合飞怙いて, $B_{2}{ }^{\prime}=0$ の代りマ $B_{2}{ }^{\prime}=1 / 10 B_{2}$ と仮定すれば, 荷重作用点の曲げモーメン

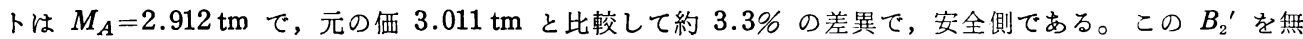
視すると，計算が非常に簡単になる。それで横曲げ剛性の省略による影響について詳しく述へるできであ るが,これは近く別に発表する予定である。 


$$
\theta\left(R_{\text {ead }}\right) \quad \text { 図 }-7
$$
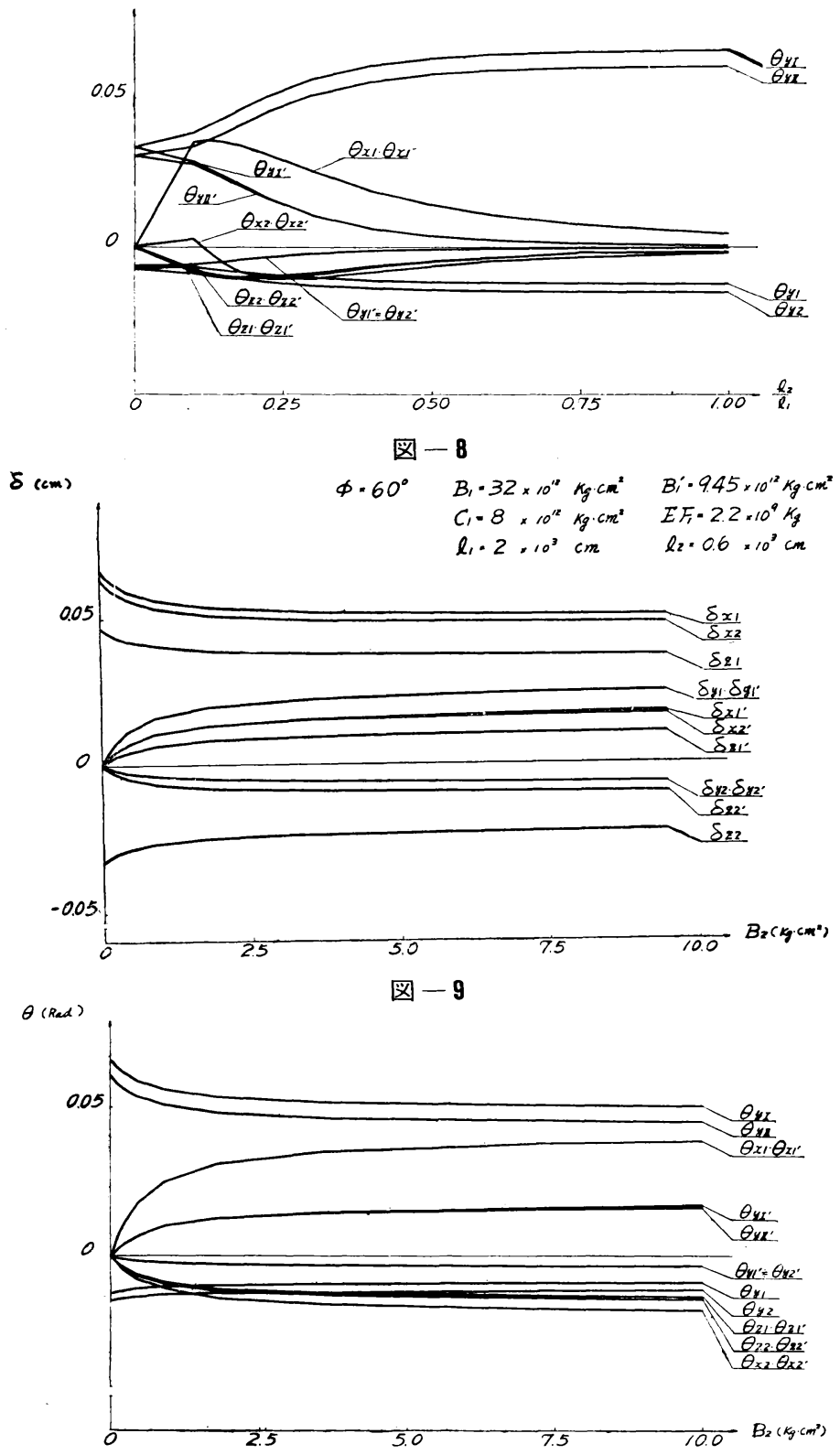

を求めればよい。ここと拘束力とし ては $\mathfrak{P}_{x}, \mathfrak{B}_{y}, \mathfrak{P}_{z}, \mathfrak{M}_{x}, \mathfrak{M}_{y}, \mathfrak{M}_{z}$ であるが，平面構造である基本的梯 形ラーメンに対する, その面内の外 力としては $\mathfrak{P}_{x}, \mathfrak{P}_{z}, \mathfrak{M}_{y}$ であり， このうち $\mathfrak{M}_{y}$ は横析のねじり剛性 を無視すれば省略され， $\mathfrak{P}_{x}$ す上 述のような仮定の下では省略され る。従つて拘束力としては $\Re_{\boldsymbol{z}}$ の みを考慮することになる。まず拘束 力の影響線を作成し(図一10), その 影響を単位荷重 $P=1$ とよる影響と 組合わせればよい。この場合も両梯 形ラーメンの影響線の緥距を重ね合 わすと, 基本的梯形ラーメン単独の ときの影響線と一致する。ここと一 例として, 図一2 (a) の場合の点 1 怙よび点 $A$ の曲げモーメントの影響 線を提示した（図一11）。（ただし脚 そは動荷重は作用しないものとす る）(影響線の縦距の単位は $\mathrm{cm}$ )。

\section{7. 結言}

（1）このような立体構造の精密 解が比較的簡単飞得られることを示 した。

（2）並列梯形ラーメンの性状の 大要を提示した。

（3）主析のねじり㧩性の影響 は，その価が比較的小であつても， これを全く無視することは適当でな い。

（4）図-3ないし 図一个示 した図表は設計の予備計算に役立つ ものである。

（5）さきに梯子桁に対して発表 した結言 ${ }^{3}$ の大部分はこの場合に も，そのまま当てはまる。

（6）梯子桁とその基本的単䋟りとの関係は，並列梯形ラーメンとその基本的梯形ラーメンとの関係と同様 である。

（7）本文は箱桁のようなねじり剛性の大きい主桁を想定して，その骨組のみについて考えたのであるが，主 桁が I 形断面のようにねじり剛性が小である場合は，床版との共同作用を考虑に入れる必要上フランジの有効幅 が問題となることはいろまでもない。

附 記 本文の計算拉よび図面作成に対し, 当教室助手湯浅, 楠本, 児島の諸君の御協力を得た。ここに厚く 謝意を表する。 
図一10 拘束力 $\mathfrak{P}_{z_{1}}$ の影響線

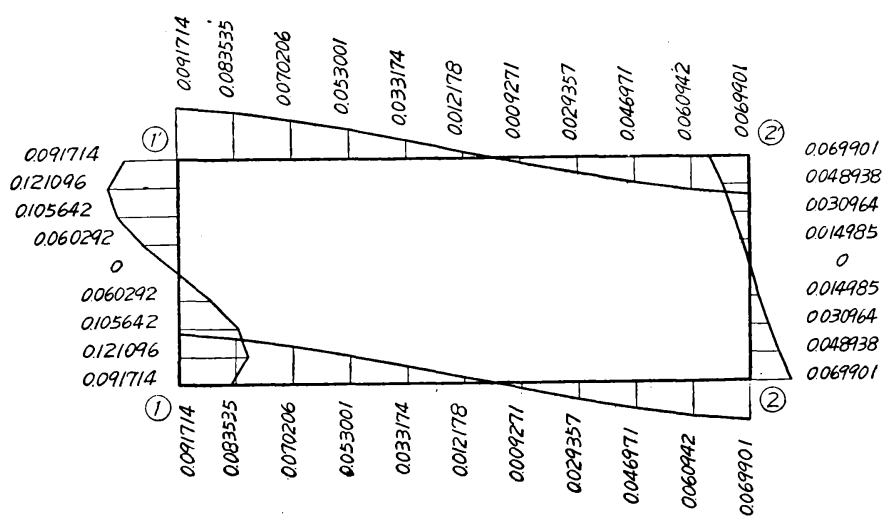

図一11(a) 点 1 の曲げモーメントの影響線

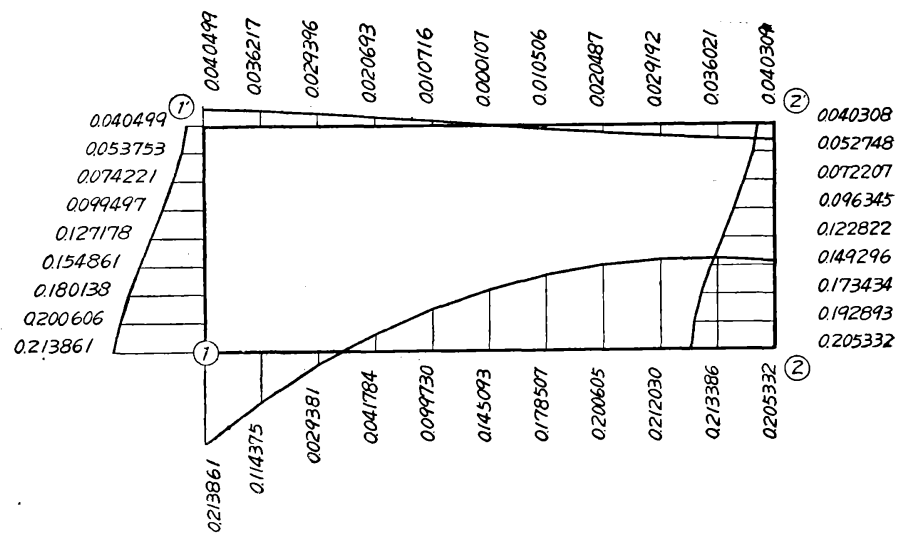

図一11(b) 点Aの曲げモーメントの影響線

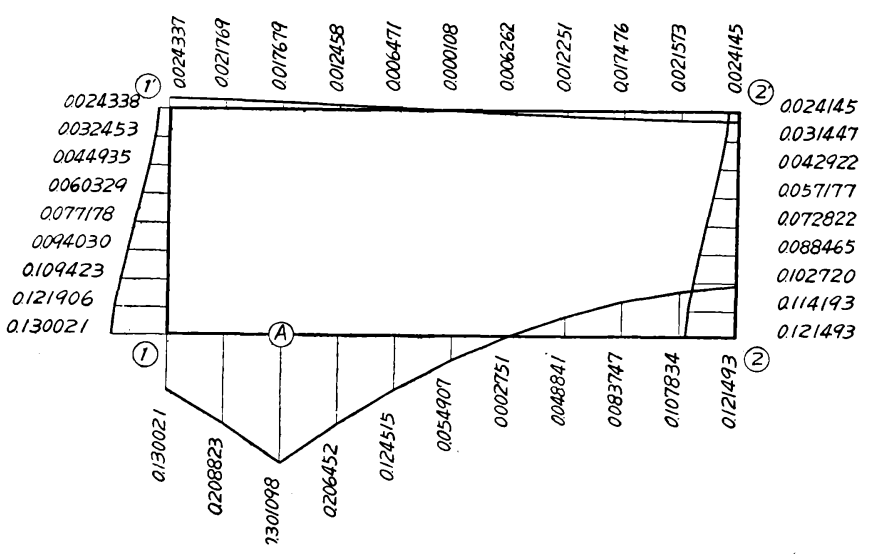

参考文献その他

1）著者かききに格子について発表した解法を抬張したものてある。”橋梁床組の計算についで士木学会誌，37 巻，8号 (1952)

2) 式 (11) は簡単のため, 節点荷重のみについて誘導したが, 中間荷重については, さきに発表したところにより（士木学会誌，39 巻 5 号), すべて節点荷重として取り扱らことができる。また摬角法の荷重項を使用することもできる。

3) 星治雄；梯子晰の荷重配分について，土木学会論文集，35 号（1956）

4）その求め方はさきに梯子析について下記により発表したところと同様でる。”梯子桁の影響線”士木技術, 11 巻 11 号 (1956)

5) 4) の文献

（昭.32.10.24） 